\title{
Tuntuuko, jos tästä painaa? Epäsuoruus, toimintaan kehottaminen ja asiantuntijuus terveydenhuollon ammattilaisten teksteissä
}

\author{
MARJA SEILONEN \\ Jyväskylän yliopisto
}

Tiivistelmä. Artikkelissa käsitellään suomea toisena kielenä käyttävien terveydenhuoltoalan ammattilaisten epäsuoraa viittaamista henkilöön ja epäsuoraa toimintaan kehottamista sekä epäsuoruuden kytkeytymistä asiantuntijuuden muunlaiseen ilmenemiseen teksteissä. Epäsuora ilmaustapa on tyypillinen erilaisissa terveydenhuollon tilanteissa, kuten potilaan ja terveydenhuollon ammatilaisen välisessä vuorovaikutuksessa ja kollegojen välisessä viestinnässä. Epäsuoraa viittausta käytetään esimerkiksi kuvattaessa jonkin ilmiön yleisiä vaikutuksia keneen tahansa henkilöön tai toisaalta tiettyyn puhuteltavaan, joka jätetään kuitenkin kielellisesti määrittelemättä. Epäsuoruus on tyypillistä myös kehotettaessa toista henkilöä toimintaan, jolloin epäsuoruudella pyritään häivyttämään kehotuksen käskevyyttä. Epäsuora ilmaustapa kuuluu lisäksi kielelliseen asiantuntijuuteen, joka voi ilmetä teksteissä sanaston ja sisällön tasolla sekä alan tekstilajin piirteinä. Tässä artikkelissa kyseisiä seikkoja tarkastellaan suomen kielen Yleisen kielitutkinnon kirjoittamisen osakokeen suorituksissa, joiden kirjoittajat ovat terveydenhuoltoalan koulutuksen saaneita henkilöitä.

Avainsanat: ammatillinen kielitaito; kielen oppiminen; suomi toisena kielenä; asiantuntijuus; direktiivi; epäsuora henkilöviittaus 


\section{Johdanto}

Terveydenhuollon alalla toimivien maahanmuuttajataustaisten henkilöiden suomen kielen taito on noussut viime aikoina keskusteluun (esim. Kela \& Komppa 2011; Partanen 2012; Piikki 2010; Suni 2010; 2011; Virtanen 2011). Opetus- ja kulttuuriministeriö on julkaissut aiheesta vuoden 2014 alussa muistion, joka koskee kielitaidon määrittämistä ja EU/ ETA-alueen ulkopuolella hankitun terveysalan koulutuksen täydentämistä (OKM 2014). Muistiossa työtä terveydenhuollon alalla kuvataan muun muassa aiheiltaan sensitiiviseksi ja nopeatilanteiseksi, "joten epäsuoruus, persoonamuotojen välttely ja ilmausten pehmentäminen on hallittava siinä missä tehokas tiivistäminen, selkeän ohjauksen antaminen ja lyhenteiden käyttökin" (OKM 2014: 29).

Käsittelen tässä artikkelissa maahanmuuttajataustaisten, suomea toisena kielenä käyttävien terveydenhuollon ammattilaisten kirjoittamia tekstejä, jotka he ovat tuottaneet suomen kielen Yleisen kielitutkinnon (YKI) kirjoittamisen osakokeen suorituksena. Tarkastelen teksteistä kielellistä epäsuoruutta, joka liittyy ensinnäkin henkilöviittauksiin ja toiseksi toimintaan kehottamiseen. Pohdin myös, miten epäsuoruuden ilmaukset kytkeytyvät terveydenhuollon asiantuntijuuden muunlaiseen tekstuaaliseen ilmenemiseen, esimerkiksi ammattisanaston tai laajemmin ammattigenren tasolla.

Epäsuorissa henkilöviittauksissa viittauksen kohde jätetään tekstin pintatasolla tarkoituksellisesti avoimeksi. Tällöin viestin tulkinnassa se, kenestä oikeastaan puhutaan, jää viestin vastaanottajan itsensä pääteltäväksi. Vastaanottaja saa kuitenkin tulkintaansa varten vihjeitä tekstiyhteydestä, joka joillakin muilla tavoin kertoo, millaista referenttiä hänen tulisi viittauksen kohteeksi ajatella. (Esim. Seilonen 2013: 40-43.) Epäsuorissa henkilöviittauksissa edustuu deiktinen ilmaustapa, jossa ilmaukset saavat merkityksensä kulloisenkin puhetilanteen kontekstin tai tekstiyhteyden perusteella. Esimerkiksi lääkärin vastaanotolla potilasta tutkittaessa kysymys Tuntuuko, jos tästä painaa? ei näytä pintatasolla viittaavan tiettyihin henkilöihin, vaan avoimeksi jää, kuka 
painaa ja kenellä tuntuu. Tilanteessa on kuitenkin selvää, että viittaukset kohdistuvat senhetkisessä toiminnassa mukana oleviin henkilöihin eli potilaaseen ja lääkäriin itseensä. Tavallisia kielellisiä epäsuoruuden rakennekeinoja henkilöviittauksissa ovat esimerkiksi passiivi (liikuntaa voidaan harrastaa kotona) ja nollapersoona (liikuntaa voi harrastaa kotona), joiden käyttö on tavallista sekä puhutussa että kirjoitetussa kielessä (esim. Hakulinen ym. 1980), sekä geneerinen yksikön 2. persoona (s(in)ä voit harrastaa liikuntaa kotona) (esim. Helasvuo \& Laitinen 2006: 201-202).

Epäsuoruutta tarvitaan erityisesti tilanteissa, joissa kuulijan tai kirjoitetun tekstin vastaanottajan toimintaan kohdistetaan odotuksia tai hänen edellytetään toimivan jollakin tavalla. Epäsuoruus on tyypillistä silloin, kun viestintätilanteen vastapuolen toimintaa pyritään jotenkin ohjailemaan esimerkiksi antamalla neuvoja tai tavoitellaan toimintaan puuttumista esimerkiksi velvoittamalla tekemään jotakin käskemällä tai kieltämällä. Toimintaan kehottamisessa epäsuoruudella pyritään antamaan kuulijalle ainakin näennäistä liikkumavaraa ja valinnanvapautta siinä, kuinka velvoittavaksi hän kehotuksen tulkitsee. Kuulijan autonomisuuden kunnioittaminen liittyy kohteliaisuuteen, joka toteutuu yhtäältä epäsuorina henkilöviittauksina ja toisaalta toimintaan kehottamisena, jossa kehotus tai pyyntö muotoillaan esimerkiksi kysymykseksi tai väitteeksi tai se ilmaistaan konditionaalin avulla (esim. Larjavaara 2007: 470, 474, 527).

Tekstit voivat ilmentää myös kirjoittajan asiantuntijuutta omalla ammattialallaan. Asiantuntijuus saattaa tulla esiin sellaisissakin teksteissä, jotka eivät varsinaisesti liity alaa käsitteleviin aihepiireihin tai ammattialaan kuuluviin tekstilajeihin. Tällaisia ovat esimerkiksi tässä artikkelissa aineistona olevat kirjoittamisen osakokeen suoritukset, joissa kirjoittajat ovat tuoneet terveydenhuollon asiantuntijuuttaan esiin monella tavalla. Asiantuntijuus ilmenee teksteissä esimerkiksi oman ammattialan tekstilajien piirteiden soveltamisena, temaattisina valintoina tai terminologian ja alalle vakiintuneiden ilmaustapojen käyttönä, joihin myös epäsuoruus olennaisesti kuuluu. 


\section{Aineisto ja menetelmä}

Tarkastelen epäsuoraa ilmaustapaa ja asiantuntijuuden esiin tuomista teksteissä, joita suomea toisena kielenä käyttävät terveydenhuollon ammattilaiset ovat tuottaneet YKI-testissä. YKI-testi on valtakunnallinen yleiskielitaitoa mittaava standardoitu, aikuisille tarkoitettu kielitaitotesti, jonka voi suorittaa kolmella tasolla (YKI-testin perusteet). Kirjoittajat (36) on identifioitu terveydenalan ammattien edustajiksi sen mukaan, mitä he ovat YKI-testin taustatietolomakkeessa itse ilmoittaneet. Koko käytetyssä aineistossa tekstejä on 108, ja ne edustavat kolmea eri tekstilajia: epämuodollinen ja muodollinen viesti sekä argumentoiva teksti. Tehtävänannon mukaan epämuodollinen viesti on suunnattu ystävälle tai hyvälle tuttavalle. Muodollinen viesti on puolestaan kohdennettu jonkin instituution edustajalle, ja kyseessä on asiointi. Suurin osa teksteistä on YKI:n keskitason kokeen suorituksia, ja mukana on myös muutama (3) ylimmän tason testin suoritus. Testiin osallistuneet ovat siis tavoitelleet vähintään kielitaidon tasoa B1 (YKI:n taso 3), jota edellytetään terveydenhuollon alalla toimivilta EU/ETA-alueen ulkopuolella ammattikoulutuksensa saaneilta ei-äidinkielisiltä suomenpuhujilta, jotta he voisivat tulla laillistetuiksi alan ammattilaisiksi Suomessa (Valvira 2014). Samaa kielitaidon tasoa vaaditaan Suomen kansalaisuuden saamiseksi, ja se on usein myös valtakunnallisen koulutuksen tavoitetasona (ns. valtakunnallinen kynnystaso ks. Latomaa ym. 2013: 176; B1-tasosta ks. Martin ym. 2010: 75). Aineistossa on kuitenkin mukana myös suorituksia, jotka eivät ole yltäneet tasolle B1. Artikkelissa ei kiinnitetä huomiota siihen, mille taitotasolle tekstit on arvioitu, sillä se ei ole tämän tarkastelun kannalta oleellista (epäsuoruuden ilmaisemisesta eri taitotasoilla ks. Seilonen 2013: 183-191).

Artikkelissa tarkastellaan sitä, millaisena epäsuora henkilöön viittaaminen ja toimintaan kehottaminen ilmenevät kirjoittajien teksteissä ja miten epäsuoruus kytkeytyy asiantuntijuuden leksikaaliseen ja tekstuaaliseen ilmentämiseen. Laadullinen lingvistinen analyysi kohdistuu muun muassa siihen, kuinka kirjoittajat ovat käyttäneet passiivia ja 
nollapersoonaa sekä geneeristä sinää teksteissään rinnakkain vaihdellen ja kuinka tarkkaa niiden käyttö on semanttisesti (vrt. Seilonen 2013: 31-32, 160-177) ja kuinka kirjoittajat ovat toimintaan kehottaessaan direktiivin eri ilmaustapoja varioimalla ottaneet huomioon vastaanottajan ja sen myötä koko tekstin odotuksenmukaisen muodollisuusasteen. Havaintoja peilataan siihen taustatietoon, että kirjoittajat ovat nimenomaan terveydenhuollon ammattilaisia. Lopuksi pohditaan tulosten merkitystä terveydenhuollon alan ajankohtaisten kehittämistarpeiden kannalta.

\section{Epäsuoruus henkilöviittauksissa}

Henkilöön voidaan viitata epäsuorasti silloin, kun puheena oleva asia halutaan kuvata ketä tahansa koskevaksi, yleiseksi ilmiöksi. Toisaalta epäsuorasti voidaan viitata myös tilanteessa läsnäolevaan puhuteltavaan tai viestin vastaanottajaan esimerkiksi silloin, kun tälle halutaan jättää viittauksen tulkinnassa liikkumavaraa. (Esim. Seilonen 2013: 1, 164.) Tilanteita, joissa epäsuoralla henkilöön viittaamisella on paikkansa, on terveydenhuollon alalla hyvin usein. Vaativimpia lienevät ne tilanteet, joissa työntekijä joutuu käsittelemään asiakkaan kannalta arkaluonteisia tai vaikeita aiheita (esim. Sorjonen 2001: 109; Kela ym. 2010: 142-148) tai kertomaan huonoja uutisia. Seuraavat vaihtelevia aihepiirejä käsittelevät esimerkkitekstit osoittavat kirjoittajien tuntevan niitä epäsuoran viittaamisen keinoja, joita he työssäänkin väistämättä tarvitsevat.

Tekstissä (1) kirjoittaja viittaa henkilöihin usein epäsuorasti yleistävässä merkityksessä. Hän käsittelee matkapuhelimen käyttöä liikenteessä ja siihen liittyviä ongelmia. Tekstissä ilmiö yleistetään ja henkilöt, jotka kirjoittajan itsensä lisäksi ovat kerronnan keskiössä, nähdään tarkemmin määrittelemättömänä joukkona. Tähän epätarkasti määriteltyyn kollektiiviin viitataan tekstissä toisaalta geneerisellä nominilausekkeella kaikki ja deiktisellä persoonapronominilla he ja toisaalta passiivilla, joka on epäsuorien henkilöviittausten tyypillinen ilmauskeino. Tekstissä kuvatut agentit eivät kuitenkaan ole täysin keitä tahansa, sillä 
liikenteen ja autolla ajamisen tekstikehys antaa niille semanttista sisältöä (ks. myös Siewierska 1984: 241). Puheena ovat siis matkapuhelinta autolla ajaessaan käyttävät autoilijat yleensä, ja kirjoittaja pyrkii tarkastelemaan ilmiötä laajemmasta näkökulmasta kuin vain henkilökohtaiselta kannalta.

(1) Liikenteessä kaikkein tärkeintä olisi turva. Kännykkäkielto kuitenkin on mennyt epäonnistumiseen. Minun mielestäni se eniten johtuu siitä, että kaikilla on kiire ja puhelimitse hoidettavia asioita sekä elämän vaikuttavia "hätätilanteita". Vaikka kaikki luulevat että heidän oma ongelma on maailman suurin järjestettävä juttu, se ei ole ollenkaan totta. Jos kuitenkin halutaan käyttä kännykkä auton ajamisen aikana, heidän kannattaa ottaa kuulokkeet käyttöön ennen lähtöä. Ajamisessa voi olla häiritseviä tapahtumia, ja jos ei huomata niitä (tai myöhässä tehdään), voidaan helposti tappaa jonkun. Liikenteessä matkapuhelimen käytöstä niissä tapauksessa täytyy ottaa suurta vastuuta. Esimerkiksi jos joudutaan menemään vaikka vankilaan, se vaikuttaa heidän ja perheensä sekä ympäristönsä elämään. Lapsia vanhempilta voi muuttua viliksi (tai viilimmiksi) jne.

Kännykkäkielto liikenteessä olisi tosi hyvä, mutta suurin kysymys: miten huomataan jos joku käyttää niitä ilman kuulokkeita, miten ja kenen avulla hoidetaan sitä? Kuuluuko se asia poliisimiehille vai?

Kirjoittaja käyttää epäsuorissa henkilöviittauksissaan paljon passiivia. Toisinaan passiivi kuitenkin tekstissä tavallaan menettää luonnettaan yleisen toiminnan kuvaajana ja tekijän taka-alaistajana (esim. ISK 2004: 1255), sillä joissakin yhteyksissä sen impersonaalisuus (esim. Sands \& Campbell 2001: 282) kumoutuu. Näin tapahtuu esimerkiksi pää- ja sivulauseen käsittävissä yhdyslauseissa, joissa toinen lause rakentuu passiivisen verbin ympärille ja toisessa taas samaan tarkoitteeseen viitataan persoonapronominilla (ja possessiivisuffiksilla): Jos kuitenkin halutaan käyttä kännykkä auton ajamisen aikana, heidän kannattaa ottaa kuulokkeet käyttöön ennen lähtöä.; Esimerkiksi jos joudutaan menemään vaikka vankilaan, se vaikuttaa heidän ja perheensä sekä ympäristönsä elämään. Esimerkkilauseissa passiivi viittaa tarkentamattomaan referenttiin ja kuvaa yleistäen tilannetta, jossa matkapuhelinta halutaan 
käyttää ajettaessa ja joudutaan (tästä aiheutuvan tapahtumaketjun vuoksi) vankilaan. Monikon 3. persoonan pronomini heidän (kuten myös possessiivisuffiksi) taas viittaa spesifiin tarkoitteeseen, mutta on yhtä aikaa kuitenkin myös samatarkoitteinen passiivin kanssa. Passiivin ja persoonapronominin viittaukset ovat näin ristiriidassa keskenään.

Passiivi siis viittaa esimerkkitekstissä tekijänä olevaan kollektiiviin, mikä on luontevaa, sillä passiivin ilmaisema tekijä mielletään useimmin monikolliseksi (ISK 2004: 1256). Monet kirjoittajan kuvaamista tapahtumista ovat kuitenkin sellaisia, että ne edellyttävät pikemminkin yksilötekijää, jolloin idiomaattisempi rakenteellinen valinta saattaisi olla nollapersoona (ks. Seilonen 2013: 46-47). Autolla ajaminen on yksittäisen henkilön toimintaa ja vankilaan meneminen koskee kokemuksena yleensä yksilöä, joten näihin olisi luontevaa viitata nollapersoonalla. Nollapersoonahan viittaa sekin henkilöön epäsuorasti, joten tekstin yleistävä näkökulma säilyy silloinkin, kun referenttinä on epätarkasti määritellyn joukon sijasta kuka tahansa yksittäinen henkilö (vrt. Jos kuitenkin haluaa käyttää kännykkää autoa ajaessa, kannattaa ottaa kuulokkeet käyttöön ennen lähtöä.). Passiivilla ja nollapersoonalla näyttää olevan myös jonkinlainen merkitysero, joka liittyy kuvatun tapahtuman toteutumisen todennäköisyyteen. Esimerkiksi lauseissa voidaan helposti tappaa jonkun tai Esimerkiksi jos joudutaan menemään vaikka vankilaan passiivi saa aikaan merkitysvivahteen, jossa tappaminen ja vankilaan joutuminen tuntuvat ilmeisemmin toteutuvilta eivätkä ole vain mahdollisia tapahtumia. Passiiviin näyttää lisäksi liittyvän merkityskomponentti, joka viittaa tapahtuman reaalisuuteen, kun taas nollapersoona kuvaa enemmänkin vain tapahtuman potentiaalisuutta. Nollapersoonan avulla ilmaisusta olisi tässäkin tekstissä tullut semanttisesti tarkempaa ja täsmällisempää sekä varioivampaa. Rakenne ei ilmeisesti kuitenkaan kuulu kirjoittajan kielelliseen välineistöön toisin kuin seuraavan kirjoittajan:

(2) Pitää harrastaa liikuntaa sännöllisesti. Mahdollisesti kolme-neljä kerta viikossa. Pitää syödä tervellistä ruokaa. Ei kannatta tupakoida, ei kannatta juoda liika alkoholia. Pitää ajaa autoa turvallisesti. Lapsudessa se 
on isän ja äidin vastuu, sen jälkeen kaikkille on oma vastuu. Mutta se ei ole niin helpoa.

Tekstissä (2) kirjoittaja on listannut terveellisen elämäntavan sääntöjä ja ohjeita nesessiivi-ilmauksia varioiden. Osa ohjeista on muotoiltu välttämättömyydeksi ja osa taas kannattavuudeksi. Kirjoittajan mukaan säännöllinen liikunnan harrastaminen, terveellisen ruoan syöminen ja maltillinen autolla ajaminen ovat välttämättömiä toimintoja, mutta tupakointi ja runsas alkoholin käyttö ovat enemmän valinnanvaraisia, sillä sellainen toiminta esitetään tekstissä vain ei-kannattavaksi. Lauseiden nollapersoonaisuus implikoi, että ohjeet koskevat yleisesti ketä tahansa (ks. Seilonen 2013: 46). Määrittelemättömään yksilöön tekijänä voidaan viitata myös geneerisessä merkityksessä käytetyllä yksikön 2. persoonalla, kuten esimerkkitekstissä (3).

(3) Liikunta autta ihmiset niin että verenvuoto on hyvä. Liikuntaminen on hyvä kokovartaloon. se on eritapoja miten tehdaan esimerkiksi kädeen, rintakehoon, vatsaan ja jalaan. Se rippu, mitä sinä haluat jös vähentään rasvaa vatsassa tai ennemään lihaksi.

Kun liikunta tehdaan, koko vartalo tulee paras, vahva, ei voi saada tauti tai ei voi tulee sairaukseksi helposti, koska lihas on aktiivinen, energiaa on paljon, sinä hengitää syvään tuore ilma ja hengitää ulos CO2. Siksi minusta liikunta on paras lääke. Myös sinä voit liikunta kotona. se rippu milloin tehdaan aamulla tai illalla. Se on halvemppi kun liikunta tehdään kotona myos. Viimeksi, voi tehdä liikunta kun katsomaan televisiosta saman aikaan perheen kanssa, ystävien kanssa tai työkavereiden kanssa. Liikunta voi tehdaan kavellamalla, jumpamalla, jouksemalla, tansimalla, laulamalla, näyrättämallä, keskustelemalla.

Tekstissä kirjoittaja käyttää nollapersoonaa ja geneeristä sinää rinnakkain puhuessaan liikunnan harrastamisesta ja sen hyödyistä yksittäisen henkilön kannalta. Nollapersoona esiintyy kirjoittajalla tosin vain modaaliverbin voida yhteydessä (ei voi saada tauti tai ei voi tulee sairaukseksi helposti), mikä onkin nollapersoonaisista ilmauksista tavallisimpia sekä syntyperäisten kielenkäytössä (Jokela 2012: 75, 213) että 
suomen kielen oppijoilla (Seilonen 2013: 145). Muulloin kirjoittaja viittaa tavalliseen liikunnanharrastajaan yleistävällä persoonapronominilla sinä (se rippu, mitä sinä haluat jös vähentään rasvaa vatsassa tai ennemään lihaksi). Tekstissä esiintyy myös passiivin avulla tapahtuvaa epäsuoraa viittaamista, jolloin referentti on irrelevantti ja kuvattu toiminta yleistetään.

Kirjoittajan teksti on kiinnostava näyte kielitaidosta, jossa rakenteiden hallinta on heikohkoa, mutta vahvuuksina ovat taito yleistää epäsuorin viittauksin ja aiheeseen sopivan terveyteen liittyvän sanaston tuntemus. Epäsuoruus, passiivin ja yksipersoonaisten ilmausten käyttö voivat tässä kaiuttaa terveydenhuollon päivittäisgenrejen kielellisiä konventioita, jotka ovat tyypillisiä esimerkiksi kotihoito-ohjeille ja kirjausohjelmaan laadittaville raporteille.

\section{Toimintaan kehottaminen}

Terveydenhuoltoalalla työhön kuuluvat keskeisesti erilaiset neuvot ja ohjeet, joilla puhuteltavaa asiakasta, potilasta tai työtoveria kehotetaan toimimaan esitetyllä tavalla. Ohjailevassa tehtävässä käytetyt lausumat ovat direktiivejä, joilla voidaan käskeä, kehottaa, pyytää, ehdottaa tai neuvoa puhuteltavaa toimimaan tai kieltää tai varoittaa häntä toimimasta tietyllä tavalla (ISK 2004: 1560). Prototyyppinen direktiivin ilmaustapa on imperatiivilause, mutta toimintaan kehottamiseen on vakiintunut muitakin ilmaustyyppejä kuten esimerkiksi indikatiivinen tai konditionaalinen väitelause tai kysymyslause (ISK 2004: 1561-1562). Imperatiivilla toimintaan kehottaminen on yksiselitteisen suoraa eikä puhuteltavalle jää edes näennäistä mahdollisuutta ymmärtää annettua ohjetta, neuvoa, kehotusta tai kieltoa toisin. Kun toimintaan kehottaminen on sen sijaan muotoiltu kysymykseksi tai väitteeksi, jossa itse puhuja fokusoituu toiveen tai pyynnön esittäjänä, kehottaminen kohdistuu puhuteltavaan epäsuoremmin ja antaa tälle enemmän tulkinnanvaraa.

Olennaista toimintaan kehottamisen kielellisessä muuntelussa on sen toiminnan luonne, jota kehotus koskee (Sorjonen 2001: 108-109). 
Tämä taas vaikuttaa siihen, miten vaikeaa yhtäältä pyytäminen ja toisaalta pyyntöön suostuminen on.

Suora kehottaminen käskylauseella ei ole aineiston teksteissä kovin tavallista edes silloin, kun viestin oletettuna vastaanottajana on ystävä tai tuttava, jota voi lähestyä epämuodollisesti ja jonka ohjailussa kirjoittaja kenties voisi ottaa tiettyjä vapauksia. Seuraavissa epämuodollista viestiä edustavissa esimerkkiteksteissä (4) ja (5) vastaanottajaa on kuitenkin suoraan kehotettu toimintaan. Teksteissä on ensin esitetty avunpyyntö, joka on kysymysmuotoinen, ja sitä seuraa suora kehotus toimia tietyllä tavalla.

(4) Voitko antaa apua minulle? Kirjoita reseptille tulehduskipulääkettä, antibioottia esim. Amonon ja lisää sairauslomaa.

(5) Voisitko ystävällisesti auttaa minua? Jos sinulla on vapaa-aikaa ja vapaa 500 euroa, se on hyvin auttaa! Vasta minulle tänään!

Avunpyyntö on näissä teksteissä ikään kuin vaativampi pääkysymys, joka pitäisi ratkaista, ennen kuin pyynnön yksityiskohtiin voidaan mennä. Ensin on siis selvitettävä, onko vastaanottaja ylipäätään halukas osallistumaan kirjoittajan ongelmien ratkaisemiseen. Pyyntö esitetäänkin kysymyksenä tilanteen tietynlaisen arkaluonteisuuden vuoksi, sillä vastaanottajan reaktioista avunpyyntöön ei voi olla varmuutta, olipa tämä tuttu tai ei. Pyyntöä seuraavat toimintakehotukset taas voivat olla suorempia, sillä niihin ei sisälly samalla tavoin puhuteltavan auttamishaluun vetoamista. Kummassakin esimerkkitekstissä vastaanottajaa kehotetaan käskylauseella kirjoittamaan eli konkreettiseen toimintaan: ensimmäisessä esimerkissä kirjoitettavana on resepti ja toisessa pikainen vastaus viestiin. Kehotuksen suoruus implikoi sitä, että kirjoittamispyyntö on sekä kirjoittajan että vastaanottajan kannalta ongelmaton ja sen esittämistä on mahdollista pitää itsestään selvänä (ks. Sorjonen 2001: 109). Toisella kielellä kirjoittajat eivät kuitenkaan välttämättä tunne tällaista merkityksen hienosäätöä.

Aineiston teksteissä on myös muodollisia viestejä, joiden vastaanottaja on kuvitteellinen jonkin instituution tai yhteisön edustaja. Kielellisenä toimintana muodollisen viestin laatiminen vastaa asiointia, jossa 
vastaanottajana on asiakaspalvelija tai asioista vastaava henkilö. Tarkemmin identifioimatta jäävälle vastaanottajalle osoitetut pyynnöt esitetään näissä teksteissä tavallisimmin väitelauseena, jossa näkökulma on puhujan ja predikaattina esimerkiksi verbi pyydän toivon tai vaadin, kuten seuraavissakin esimerkeissä (6) ja (7) on laita.

(6) Pyydän reagoida mahdollisimman nopeasti.

(7) Toivosin että nuo tavaroita lähteä minulle nopeasti.

Esimerkeissä kirjoittajat kehottavat virkailijaa kiirehtimään, mutta tekevät sen niin, että kirjoittajan oma toiminta korostuu. Kirjoittaja pyytää ja toivoisi, että toimitaan pikaisesti, ja pyyntö kohdistuu henkilöön, johon viitataan ei-persoonamuotoisella verbillä reagoida ja lähteä [lähetetään?] (passiivin korvautumisesta 1. infinitiivin muodolla oppijankielessä ks. Seilonen 2013: 60).

Esimerkeissä (8) ja (9) kirjoittajat yrittävät saada mielestään aiheettomasti langetetun sakon perutuksi. Esimerkin (8) kirjoittaja aloittaa pyyntönsä ironisin kiitoksin ja kehottaa sitten toiveen muodossa perumaan sakon tai pienentämään sitä. Tekstin sävy jatkuu neutraalina, ja viittaus sakkojen määräämisestä päättävään henkilöön on epäsuora. Kirjoittajan käyttämä passiivi viittaa epätarkasti määriteltyyn henkilötarkoitteeseen, joka ei välttämättä ole sama kuin edellisessä lauseessa mainittu tarkastaja. Suora persoonaviittaus ei olekaan tässä tarpeen, jos tavoitteena on vain tietyn toiminnan aikaansaaminen, ei toiminnan henkilöiminen tiettyyn toimijaan.

(8) Kiitän tarkastajan ahkerasta työstä, mutta toivon, että parkkisakko jätettäisi pois tai sakkorahoja vähennettäisi huomattavasti!

(9) Vaatin että minulle annettu sakko peruutetaan, olen maksanut jo sakkoni, ystävällisesti maksakaa rahani takaisiin tilille: 10----22 nordea.

Esimerkin (9) kirjoittaja puolestaan edellyttää vastaanottajalta toimenpiteitä kovemmin äänenpainoin ja suoremmin, mikä osoittaa, että hän ei asemoi itseään tilanteessa altavastaajaksi. Kirjoittaja vaatii, mihin hän katsoo olevansa oikeutettu, sillä hän on jo noudattanut saamaansa määräystä eli maksanut sakon. Toimintaan kehottaminen on 
kuitenkin jyrkkäsävyistä vain leksikaalisesti, kun pääverbiksi on valittu vaatia, mutta direktiivin ilmaisutapa on kuitenkin epäsuora. Tässäkin esimerkissä näkökulma on puhujan, jonka toiminnasta käsin tilannetta kuvataan, ja passiivi taka-alaistaa henkilötekijän, johon toimintaan kehottaminen kohdistuu. Koska kirjoittaja kokee olevansa asiassa oikeassa, hän voi antaa imperatiivia käyttäen myös suoran kehotuksen konkreettiseen toimintaan. Samalla hän myös viittaa persoonamuodolla suoraan henkilöön. Maksamiskehotuksen käskevyyttä kirjoittaja kuitenkin lieventää sanalla ystävällisesti.

Toimintaan kehottamisen erilaiset toteumat ovat kontekstisidonnaisia (Tanner 2012: 68; Sorjonen 2001: 108), eli erilaisissa tilanteissa ovat käytössä erilaiset kehottamisen kielelliset ilmaisutavat ja toisaalta käytetyt ilmaisutavat kertovat tilanteen luonteesta. Ilmaustavan valinnassa keskeistä on myös se, keitä tilanteessa on mukana ja minkälaiseen toimintaan ollaan kehottamassa. Jos kyseessä on esimerkiksi toiminta, joka ei vaadi vastaanottajalta paljon erityistä henkistä tai fyysistä vaivannäköä ja jonka sosiaalinen etäisyys vuorovaikutukseen osallistuvilla ei ole pitkä, toimintaan kehottaminen voi olla suorempaa (esim. Brown \& Levinson 1987 [1978]: 74-84). Toisaalta pyynnön suuruus, osallistujien valta ja sosiaalinen etäisyys menettävät merkityksensä asiointitilanteissa, joissa osanottajilla on valmiiksi määritellyt roolit: toinen on asiantuntija ja toinen asiakas (Tanner 2012: 165; Honkanen 2012: 91). YKI-testin muodollisen viestin kirjoittaminen on sekin asiointitehtävä, sillä siinä otetaan yhteyttä asiakaspalvelijaan, asioista vastuussa olevaan tai asiantuntijaan.

Kirjoittajat näyttävät osaavan hyvin sellaisia toimintaan kehottamisen tapoja, joita he työssäänkin tarvitsevat. Tätä osaamistaan he tuovat myös hyvin esiin YKI-testin kirjoitustehtävissä. 


\section{Asiantuntijuus teksteissä}

Kirjoittajien terveydenhuoltoalan asiantuntijuus tulee esiin useissa heidän teksteissään, vaikka yleiskielitaitoa mittaavan testin tehtävänanto itsessään ei siihen ohjaakaan. Tämä voi tapahtua sisällöllisinä tai kielellisinä valintoina. Terveydenhuoltoalan suomi on olennainen osa kirjoittajien suomen kielen taidon kokonaisuutta, joka muodostuu suomen kielen yleisestä taidosta ja ammattialan erikoiskielen osaamisesta. Suomenkielisen terveydenhuoltoalan kielen hallinta muodostaa ilmeisen keskeisen komponentin myös kirjoittajien asiantuntijuudessa ja ammattitaidossa. Alan kielen hallinta on siten osa paitsi kielitaitoa myös ammattitaitoa (ks. Härmälä 2008: 53) ja lopulta myös henkilön identiteettiä (ks. Virtanen 2013). Asiantuntijuus voi teksteissä ilmetä esimerkiksi oman ammattialan tekstilajien piirteiden tai rekisterien soveltamisena - mukaan lukien juuri epäsuoruuden keinojen hallinta - temaattisina valintoina tai terminologian ja alalle vakiintuneiden ilmaustapojen käyttönä.

Teksteistä syntyy usein vaikutelma, että kirjoittajat ovat panostaneet varsinkin alan sanaston ja ilmaisujen oppimiseen ja tuovat oppimaansa mielellään esiin (esimerkki 10). Teksti saattaa sisältää terveydenhuoltoon liittyvää sanastoa runsaastikin, vaikka esimerkiksi rakenteiden hallinta olisi vielä vaatimatonta ja epätarkkaa.

(10) Liikunta on paras lääke, taman asiasta on totta, minä sämä mielta koska liikunta ennaltaehkkäisy erilainen sairauksia, kuten aivonhalvaus, lihava, sydamentauti mm. Liikunta vahvaus vartalo tai ruumis, virkistynyt mielensa ja se antaa energia tehda tyotä kaksi-kolme kertaa viikossa liikkelle asunnon ymparilla tai puistoon vahentaa stressia eli rentoudu jossa autaamaan ihmistä terveyksia. Myös, millainen liikunta sopeutua ihmineseen kykyseen on tärkeää osa liikunnan osallistua. Sairauksen jalkeen liikunta on paras regoida nopeasti, jotta ihminen jatkuva omansa elämänsä. Liikunta aina terveyksi.

Liikuntaa käsittelevästä tekstistä (esimerkki 10) syntyy vaikutelma, että kirjoittaja on sellaisessa kielenoppimisen vaiheessa, jossa opitaan 
ilmauksia sellaisenaan niitä tarkemmin erittelemättä tai analysoimatta (ks. Ellis 2005: 75-76). Kirjoittaja ei muun muassa näytä tunnistavan käyttämiensä sanojen sanaluokkaa, sillä esimerkiksi nominit tai nominaalimuodot voivat toimia tekstissä toisinaan finiittiverbin tehtävässä (liikunta ennaltaehkkäisy erilainen sairauksia; Liikunta vahvaus vartalo; jotta ihminen jatkuva omansa elämänsä).

Käytetty spesifi terveydenhuollon termistö ja alan konventionaalistuneet ilmaustavat voivat myös vaikuttaa siten, että kirjoittajan käyttämä rekisteri poikkeaakin oletetusta. Kirjoittaja voi tekstissään osoittaa osaavansa alan sanastoa paljonkin, mutta ei mahdollisesti tunnekaan vaihtoehtoisia tapoja ilmaista samoja asioita. Rajallinen sanaston hallinta voi estää kirjoittajaa tekemästä muodollisen ja epämuodollisen rekisterin edellyttämiä leksikaalisia valintoja. Siten kirjoittaja ei esimerkiksi välttämättä osaa puhua sairastamisesta ja sairauksista arkisesti, kuten ei esimerkkitekstin (11) kirjoittajakaan. Toisaalta hän ei kenties haluakaan tehdä niin, sillä kyseessä on testitilanne, jossa on tarkoitus tuoda esiin oman kielitaidon vahvuuksia ja osoittaa taidon riittävyys testin läpäisemiseen.

(11) Hei Sofia!

Olen sairastunut. Tänään en käynyt työssä vielä, olen sairauslomalla viime tiistaista lähtien. Kaksi viikkoa sitten minulla on ollut flunssa ja nyt minun korvani on kipeää, lisäksi oireina on nenävuotaa ja poskissa on paineen tunnetta. Kuumetta ei ole ollut eikä kurkkukipuakaan. Talven tullen aloitan hiihdon ulkona, joka on hyvää urheilua. Kuntosalin harjoitteen rinnalla se vaikuttaa tasapainoon myös. Mutta vielä minulla ei ole ollut välikorvatulehdusta koskaan. Ulkona on tosi kylmää... Terveisin Peter

Edellä olevassa epämuodollisessa viestissä (11) kirjoittaja kuvaa melko tarkasti sairauttaan ja sen oireita - ehkä liiankin tarkasti, kun vastaanottajana on ystävä. Lisäksi käytetyt ilmaustavat poikkeavat siitä, kuinka tämäntyyppisestä asiasta on tapana arkikielellä ystävien kesken puhua. Teksti muistuttaakin joiltakin piirteiltään lääkärin hoitokertomusta tai epikriisiä. 
Seuraava reklamaatio (12) on suunnattu ravintolalle, jonka tarjoamasta ruoasta kirjoittaja epäilee saaneensa ruokamyrkytyksen.

(12) Terve! Minulla on iso ongelma. Viimeisenä lauantaina olen kiinalaisessa ravintolassa. Olen syönyt lihaa, perunoita ja sammakoita. Seuravana paivänä minulla oli kuumotusta, närästystä, oksentelua ja vatsa kipeytynyt koko päivä. Lääkket eivät auttaneet. Hakeutunut ensiavuun. Siellä oli tutkimuksia, labrakokeet ja sitten hoitanut kirurgisen osastolla. Siellä saanut lääkeitä suonensisäisesti ja suun kautta. Olin sairaalassa 5 päivän ajan. Mielestäni, liha ei ollut tosi hyvin paistettu. Haluaisin, että minun raha tulee takaisin ja kaikki lääkkeet te maksatte. Uskon, että tilanne selvitetään. Varmasti, teidän ravintola on upea, mutta silloin ei ollut teidän päivä. Kiitän, jos ymmärätte minua. Odotan vastausta.

Terveisin Axel

Sisällöllisesti kirjoittajan teksti koostuu ongelman ja sen taustojen esittelystä, oireiden ja hoidon yksityiskohtiin menevästä kuvauksesta, ongelman syyn toteamisesta, korvausvaatimusten esittämisestä ja sitä seuraavasta pehmentävästä, hyvittelevästä ja yhteistyöhakuisuutta ilmaisevasta jaksosta. Rekisteriltään teksti noudattaa pääpiirteissään muodollisia konventioita lukuun ottamatta kuitenkin esimerkiksi aloitusta ja lopetusta, jotka ovat tuttavallisia ja siten muodolliseen tekstiyhteyteen epäsopivia.

Ruokamyrkytysepäilyn taustojen esittelyn jälkeen kirjoittaja siirtyy kuvaamaan myrkytyksen aiheuttamia oireita ja saamaansa hoitoa, jolloin hänen asiantuntijuutensa tulee tekstin tasolla vahvasti esiin. Sairauksiin ja sairaanhoitoon liittyvä aihepiiri ilmeisesti johdattelee hänet vielä käyttämään osittain ilmaisutapaa, joka on tyypillinen sanelulle tai sairaanhoitajan työssään käyttämälle kirjausohjelmalle. Tässä terveydenhuollolle ominaisessa tekstilajissa yhtenä tavoitteena on tiivis ilmaisu, tekstin lyhyys ja asian etäännyttäminen. Tästä syystä sanelu usein voikin olla paikoin lyhytlauseista (Lääkket eivät auttaneet. Hakeutunut ensiavuun.) ja luettelomaista (Seuravana paivänä minulla oli kuumotusta, närästystä, oksentelua ja vatsa kipeytynyt koko päivä.) ja siihen kuuluu 
tunnusomaisena yhdysverbien elliptinen käyttö, jossa apuverbi jää pois (Siellä saanut lääkeitä suonensisäisesti ja suun kautta.). Näin käytettynä pelkkä partisiippimuoto lähenee merkitykseltään passiivi-ilmausta, sillä siinä persoonaa korostava elementti on jäänyt pois (hakeutunut hakeuduttu ensiapuun; siellä saanut saatu lääkkeitä). Persoonaa häivyttäessään tällainen partisiippi-ilmaus myös synnyttää tekstiin epäsuoruutta. Teksti kuvastaa kirjoittajan kokemusta työskentelystä terveydenhuollon alalla ja sen tuomaa asiantuntijuutta, sillä saneluteksti vaikuttaa hänelle tekstilajina tutulta samoin kuin jotkin lääketieteelliset termit ja kiteytyneet ilmaustavatkin. Kirjoittaja hyödyntää näin ennalta tutun tekstilajin piirteitä taitavasti kirjoitustehtävässä, jossa niiden käyttöä ei edellytetä.

Rakenteellisista ja leksikaalisista puutteista huolimatta kirjoittajan teksti osoittaa esimerkiksi tiettyjen kielellisten funktioiden hallintaa ja taitoa huomioida viestin vastaanottaja. Tekstissä on vahvasti persoonanäkökulma, jossa kirjoittaja viittaa suoraan sekä itseensä että viestinsä vastaanottajaan persoonapronominien ja persoonamuotoisten verbien avulla. Suorat viittaukset voivat olla kirjoittajan tietoinen valinta tekstissä, joka kuvaa nimenomaan omia kokemuksia ja näkökantoja ja jolla lisäksi on spesifi vastaanottaja, tai ne voivat olla osoituksena siitä, että kirjoittaja ei hallitse epäsuoraa viittaustapaa.

Asiantuntijuus voi teksteissä ilmetä myös terveydenhuollon tyypillisten työtilanteiden tai työnkulun kuvauksena. Muutama kirjoittaja on tehnyt tällaisen temaattisen valinnan, vaikka kirjoitustehtävän ohjeistus ei olekaan siihen varsinaisesti antanut mahdollisuutta.

(13) Olen tyossä tänään osastolla. Meidän osastolla on paljon kiire koska viikosta tämä ensimainen päivä viikkon. Aloitetaan työ vähän nopea koska meidan yks potilas on ongelmia. Hanella on sydän kipua. Tarvitse antamaan apua ja kipualääkeitta hänelle. Sitten toinen potilas pitäisi menna leikkaussalissa yksitelen. Myös meidan raportit ei valmistaa viela. Siksi meilla työta hitaasti mutta varmasti niin etta voimme lopettaa meidan työ yleensä reippasti ja huollelisesti aikaan.

Työviikon ensimmäisen päivän kiireitä osastolla kuvaa teksti (13), jossa kirjoittaja kertaa työpäivänsä tapahtumia. Mainituksi tulevat hoitotoimet 
ja hoitajan kirjallisiin töihin kuuluva raportointi (ks. myös Virtanen 2013). Tyypillistä vuodeosaston aamuvuoroa taas käsittelee teksti (14), jossa niin ikään mainitaan kiire. Kirjoittajan mukaan kiire on aamuvuoron tyypillinen piirre, joka johtuu rutiinitöiden paljoudesta. Tämän todistaakseen kirjoittaja käy läpi vuodeosaston aamuvuoron ohjelman eri työvaiheiden listana.

(14) Mielistani tämä on hyvä asiasta koska joka päivä sairaanhoitaja vuodeosasto on kiire. Aamuvuoro aina kiire; koska aamulla ruotinia (sannolisesti) paljon. Vuodeosasto ohjelma aamu- Aamupalan viedaan aamuhoitoa lääkkeitä viedaan, läkäri kiertä, toimenpide leikkaus ja rontgen. Tämä ohjelma on kiire tarvitaan ennen loppu työvuoro täytyy valmis. Minusta että tarvitaan lisää aamuvuoro sairaanhoitaja niin että joka päiva sairaanhoitaja ei kiire, ja sitten hoiton on paremmin.

Asiantuntijuus siis ilmenee aineiston teksteissä monella tavalla. Toisinaan se on kielellistä, jolloin asiantuntijuus näkyy käytetyssä termistössä ja ilmaisutavoissa sekä epäsuoran ilmaisutavan hyödyntämisessä. Asiantuntijuus tulee usein esiin myös sisällöllisesti, temaattisina valintoina, jolloin tekstit käsittelevät omaan ammattialaan liittyviä aihepiirejä.

\section{Kielitaito on ammattitaitoa}

Kielitaito on osa terveydenhuollon alalla toimivien ammattitaitoa, ja kommunikaatiota voi pitää terveydenhuollon ammattilaisten yhtenä keskeisenä työvälineenä (Candlin \& Candlin 2002; Kela \& Komppa 2011: 180; Peräkylä ym. 2001: 8). Kieli- ja viestintätaidon keskeinen tehtävä työssä koskee paitsi maahanmuuttajia myös syntyperäisiä terveydenhuollon alalla toimivia, sillä kielelliset ja kulttuuriset erot voivat tulla vastaan myös maan eri murrealueilla toimittaessa (ks. Puustinen 2002: 71; Walters 2008).

Maahanmuuttajataustaisilla terveydenhuollon ammattilaisilla on erityishaasteet työssä tarvittavan kielitaidon haltuun ottamisessa. Suomen taito merkitsee heillä yleistä kielen hallintaa sekä terveysalan 
erikoiskielen osaamista, jolla vahvistetaan myös ammattitaitoa. Työssä tarvittavan kielitaidon hankkiminen on vaativa tehtävä, sillä terveydenhuoltoalan työ perustuu paljolti monimuotoiseen vuorovaikutukseen työhön liittyvine erityisine viestintätapoineen (Suni 2011: 13). Esimerkiksi maahanmuuttajataustaiset sairaanhoitajat ovat pitäneet työnsä haastavimpana alueena moniammatillista yhteistyötä, jossa erilaiset erityiskielet kohtaavat, ja kielellisesti vaativia tehtäviä sisältyy heidän mukaansa myös asiakaspalveluun ja päivittäisiin rutiineihin (Kela \& Komppa 2011: 181-184). Ilmaisutapaan on tarpeellista kiinnittää erityishuomiota esimerkiksi sellaisissa asiakaspalvelun tilanteissa, joissa joudutaan kohtaamaan vaikeita potilaita, käsittelemään potilaan kannalta vaikeita tai arkaluonteisia aiheita tai kertomaan huonoja uutisia.

Kielitaidossa keskeistä on myös rekisterin hallinta, sillä tilanteeseen sopimattomat kommunikointitavat voivat johtaa väärinymmärryksiin (Duff ym. 2000: 29). Kun kielenkäyttäjän kielitaito on jo hyvä, pragmaattiset poikkeamat tulkitaan herkästi tarkoituksellisiksi eikä kielitaidon puutteista johtuviksi. Erityisesti institutionaalisessa keskustelussa pragmaattisten konventioiden rikkominen voi olla kohtalokasta (Gumperz \& Roberts 1991).

Tarkastellut terveydenhuollon alan ammattilaisten tekstit kertovat siitä, että kirjoittajat pystyvät ilmaisemaan esimerkiksi erilaisia kielellisiä funktioita erilaisissa tilanteissa. Teksteissä on usein myös pragmaattisesti oikeaan osuneita kielellisiä valintoja. Esimerkiksi epäsuorasti esitetyt kehotukset toimintaan ovat teksteissä kuvattuihin tilanteisiin sopivia ja siten pragmaattisesti toimivia. Tekstit kuvastavat paljolti myös sitä, että kirjoittajat ovat omaksuneet kieltään työympäristössä. Ammattikieleen kuuluvaa sanastoa, ilmaisuja ja tekstilajeja on hyödynnetty teksteissä monin tavoin. Ammattikielen muotoja ja käytänteitä voi työtilanteissa oppia toisten kielenkäyttäjien toimintaa havainnoiden ja itse kieltä käyttäen. Terveydenhuoltoalalla toimivat suomea toisena kielenä käyttävät pitävätkin usein juuri työyhteisöä ja äidinkielisen puhujan antamaa kielellistä apua ja tukea keskeisenä ammattikielen oppimisessa (Suni 2011: 18-19). 
Erään kirjoittajan tekstistä (15) kuvastuu reaalinen huoli, joka liittyy terveydenhuollon alalla toimivan maahanmuuttajan ammatilliseen tulevaisuuteen.

(15) Hei Kimmo! Mullakin on monta asiaa kesken. Olen osallistunut jo YKI tenteihin. Mulle jäi oudot fiilikset sen jälkeen, koska siitä rippuu saanko minä mennä Tampereelle suorittamaan tenttiä.

Ei-syntyperäisten EU/ETA-alueen ulkopuolella koulutuksensa saaneiden lääkäreiden laillistamisprosessiin kuuluu nykyisellään YKI-testin suorittaminen vähintään tasolla B1, mikä on edellytyksenä niin sanottuun Tampereen tenttiin eli lääkärin kolmiosaiseen ammatilliseen kokeeseen osallistumiselle (ks. OKM 2014: 18). Kielitaitotestin suorittamisella on siis näille lääkäreille erityistä painoarvoa.

Opetus- ja kulttuuriministeriö on muistiossaan pitänyt tarpeellisena erityisen ammatillista kielitaitoa mittaavan testin järjestämistä terveydenhuollon alalle (OKM 2014: 48). Tässä artikkelissa analysoidut tekstit osoittavat, että ammatillinen kielitaito tulee jonkin verran esiin myös yleiskielitaidon testissä. Syntyy myös vaikutelma, että kirjoittajat pitävät ammattikielen osaamistaan kielitaitonsa yhtenä vahvuutena. Selvitettäväksi jää, mikä olisi jatkossa tarkoituksenmukaisin tapa osoittaa ja arvioida tätä osaamista.

\section{Lähteet}

Brown, Penelope, Stephen C. Levinson 1987 [1978]. Language and Politeness. Some Universals in Language Usage. Studies in Interactional Sociolinguistics 4. Cambridge: Cambridge University Press.

Candlin, Christopher N., Sally Candlin 2002. Discourse, expertise and the management of risk in the health care settings. - Research on Language and Interaction 35 (2), 115-137.

Duff, Patricia, Ping Wong, Margaret Early 2002. Learning language for work and life: The linguistic socialization of immigrant Canadians seeking careers in health care. - Modern Language Journal 86 (3), 397-422. http://dx.doi. org/10.1111/1540-4781.t01-1-00157 
Ellis, Nick C. 2005. Constructions, chunking and connectionism: The emergence of second language structure. - Catherine J. Doughty, Michael H. Long (Eds.). The Handbook of Second Language Acquisition. UK: Blackwell, 63-103.

Gumperz, John, Celia Roberts 1991. Understanding in intercultural encounters. - Jan Blommaert, Jef Verschueren (Eds.). The Pragmatics of International and Intercultural Communication. Amsterdam: John Benjamins, 51-90.

Hakulinen, Auli, Fred Karlsson, Maria Vilkuna 1980. Suomen tekstilauseiden piirteitä: kvantitatiivinen tutkimus. Publications 6 / Department of General Linguistics. Helsinki: University of Helsinki.

Helasvuo, Marja-Liisa, Lea Laitinen 2006. Person in Finnish: Paradigmatic and syntactic perspectives. - Marja-Liisa Helasvuo, Lyle Campbell (Eds.). Grammar from the Human Perspective: Case, Space and Person in Finnish. Current Issues in Linguistic Theory 277. Amsterdam: John Benjamins, 173-207.

Honkanen, Suvi 2012. Kielioppi ja tekstilaji. Direktiivin muotoilusta viraston ryhmäkirjeissä. Helsinki: Helsingin yliopisto.

Härmälä, Marita 2008. Riittääkö Ett ögonblick näytöksi merkonomilta edellytetystä kielitaidosta? Kielitaidon arviointi aikuisten näyttötutkinnoissa. Jyväskylä Studies in Humanities 101. Jyväskylä: Jyväskylän yliopisto.

ISK = Hakulinen Auli, Maria Vilkuna, Riitta Korhonen, Vesa Koivisto, Tarja Riitta Heinonen, Irja Alho 2004. Iso suomen kielioppi. SKS:n toimituksia 950. Helsinki: Suomalaisen Kirjallisuuden Seura.

Jokela, Hanna 2012. Nollapersoonalause suomessa ja virossa. Tutkimus kirjoitetun kielen aineistosta. Turun yliopiston julkaisuja, sarja C osa 334. Turku: Turun yliopisto.

Kela, Maria, Eveliina Korpela, Päivi Lehtinen 2010. Sairaan hyvää suomea. Terveydenhuoltoalan suomea maahanmuuttajille. Helsinki: Edita.

Kela, Maria, Johanna Komppa 2011. Sairaanhoitajan työkieli: yleiskieltä vai ammattikieltä? Funktionaalinen näkökulma ammattikielen oppimiseen toisena kielenä. - Puhe ja kieli 31 (4), 173-192.

Larjavaara, Matti 2007. Pragmasemantiikka. SKS:n toimituksia 1077. Helsinki: Suomalaisen Kirjallisuuden Seura.

Latomaa, Sirkku, Sari Pöyhönen, Minna Suni, Mirja Tarnanen 2013. Kielikysymykset muuttoliikkeessä. - Tuomas Martikainen, Pasi Saukkonen, Minna Säävälä (Toim.). Muuttajat. Kansainvälinen muuttoliike ja suomalainen yhteiskunta. Helsinki: Gaudeamus, 163-183. 
Martin, Maisa, Sanna Mustonen, Nina Reiman, Marja Seilonen 2010. On becoming an independent user. - Inge Bartning, Maisa Martin, Ineke Vedder (Eds.). Communicative Proficiency and Linguistic Development: Intersections Between SLA and Language Testing Research. EUROSLA. Monographs Series 1. European Second Language Assosiation. Rome, Italy: Edisegno srl, 57-80.

OKM 2014. Kielitaidon määrittäminen sekä kielitaidon ja EU/ETA-alueen ulkopuolella hankitun koulutuksen täydentäminen terveysalalla. Opetus- ja kulttuuriministeriön työryhmämuistioita ja selvityksiä 2014:5. Helsinki: Opetus- ja kulttuuriministeriö.

Partanen, Maiju 2012. Matkalla sairaalaan: maahanmuuttajien käsityksiä suomen kielen oppimisesta sisääntuloammatissa. Pro gradu -tutkielma. Jyväskylän yliopisto.

Peräkylä, Anssi, Kari Eskola, Marja-Leena Sorjonen 2001. Lääkärin ja potilaan vuorovaikutus tarkastelun kohteena. - Marja-Leena Sorjonen, Anssi Peräkylä, Kari Eskola (Toim.). Keskustelu lääkärin vastaanotolla. Tampere: Vastapaino, 7-26.

Piikki, Anni 2010. Terveydenhoitoalalla riittävä suomen taito - mitä se on? Sutina 1, 30-33.

Puustinen, Raimo 2002. Potilaan käsikirja. Johdatusta lääketieteen maailmaan. Helsinki: WSOY.

Sands, Kristina, Lyle Campbell 2001. Non-canonical subjects and objects in Finnish. - Alexandra Y. Aikhenvald, Robert M. W. Dixon, Masayuki Onishi (Eds.). Non-Canonical Marking of Subjects and Objects. Amsterdam: Benjamins, 251-305.

Seilonen, Marja 2013. Epäsuora henkilöön viittaaminen oppijansuomessa. Jyväskylä Studies in Humanities 197. Jyväskylä: Jyväskylän yliopistopaino.

Siewierska, Anna 1984. The Passive: A Comparative Linguistic Analysis. London: Routledge.

Sorjonen, Marja-Leena 2001. Lääkärin ohjeet. - Marja-Leena Sorjonen, Anssi Peräkylä, Kari Eskola (Toim.). Keskustelu lääkärin vastaanotolla. Tampere: Vastapaino, 89-111.

Suni, Minna 2010. Työssä opittua. Työntekijän näkökulma ammatilliseen kielitaitoonsa. - Mikel Garant, Mirja Kinnunen (Toim.). AFinLa-e. Soveltavan kielitieteen tutkimuksia 2. Jyväskylä: AFinLa, 45-58.

Suni, Minna 2011. Missä ja miten maahanmuuttajat kehittävät ammatillista kielitaitoaan? - Ammattikasvatuksen aikakauskirja 2, 8-22. 
Tanner, Johanna 2012. Rakenne, tilanne ja kohteliaisuus. Pyynnöt S2-oppikirjoissa ja autenttisissa keskusteluissa. Helsinki: Helsingin yliopisto.

Valvira 2014. Kielitaito. www.valvira.fi/luvat/ammattioikeudet/kielitaito (2.9.2014).

Virtanen, Aija 2011. Käsityksiä kansainvälisesti rekrytoitujen hoitajien ammatillisesta kielitaidosta ja sen kehittymisestä. Mediakeskusteluiden ja asiantuntijan haastattelun analyysia. - Puhe ja kieli 31 (4), 153-172.

Virtanen, Aija 2013. Minä sairaanhoitajana: tulevaisuuden minuudet motivaatiota muokkaamassa. - Lähivõrdlusi. Lähivertailuja 23, 403-427. http://dx.doi. org/10.5128/LV23.16

Walters, Helen 2008. The experiences, challenges and rewards of nurses from South Asia in the process of entering the Australian nursing system. Australian Journal of Advanced Nursing 23 (3), 95-105.

YKI = Yleisten kielitutkintojen perusteet. www.jyu.fi/hum/laitokset/solki/yki (2.9.2014). 


\title{
Does it hurt, if one presses here? Indirectness, urging action and professionality in the texts of health care professionals
}

\author{
MARJA SEILONEN \\ University of Jyväskylä
}

This article focuses on the indirect personal reference, indirect urging action and indirectness linked to professionality in the texts of health care professionals who use Finnish as a second language. Indirect statements are typical in various health care situations such as communication between patients and health care professionals and interaction between colleagues. Indirect references are often used to describe the general impact of some occurrence e.g. to a nonspecified person (whoever) or to a certain undefined addressee. Indirectness is common also in expressions, where the imperative nature of the request is softened by using indirectness. Indirectness also has a role in professional language where professionality can be expressed lexically, textually or thematically. In this article these issues are studied in the written Finnish texts of qualified health care professionals partaking in the Finnish National Certificate of Language Proficiency tests.

Keywords: professional language skills; language learning; Finnish as a second language; professionality; directive; indirect personal reference

\author{
Marja Seilonen \\ Jyväskylän yliopiston kielten laitos \\ PL 3540014 Jyväskylä, Finland \\ marja.a.p.seilonen@jyu.fi
}

